\title{
Exploring the utilization of technology in teaching English: Practices and impediments
}

\author{
Renu Singh \\ Tribhuvan University, Nepal
}

\begin{abstract}
The utilisation of technology into classroom practices basically promotes studentcentered instructions that require teachers to be professionally well trained and confident enough to use various technology tools and resources. This study was conducted to explore secondary school EFL teachers' experiences and practices of modern technology usage into their classroom pedagogy and possible impediments of utilizing technology tools. Eight EFL teachers were purposefully selected from public secondary schools of the Kathmandu valley. A semi-structure interview was administered to collect the required data. The thematic data analysis revealed that the EFL teachers employed different pedagogical strategies for the effective integration of technology; however, some impediments were identified such as insufficient professional ICT skills and knowledge of EFL teachers, inadequate ICT infrastructure at school, teachers' workload and time constraint, and digital device among students. This study suggests that EFL teachers need professional development trainings particularly designed on the TPACK framework, adequate ICT infrastructure at school, revised teachers' workload and time constraint, and supportive school environment to promote technology utilization into EFL pedagogy.
\end{abstract}

Keywords: Technology Utilization, TPACK, Professional Development, Constructivism, Technology Impediment, EFL

\section{Introduction}

The proliferation in ICT has drastically upgraded almost every sphere of human life in the recent time (Horovitz, 2012) (The terms ICT (information and communication technology) and technology are used synonymously henceforth). Particularly, the ubiquitous nature of ICT has greatly penetrated developed and developing countries around the globe to move further in the direction of advancement. Thus, "with the expanding role of information and communication technology (ICT) in all areas of life, Ministry of Education (MoE) considers the use of and knowledge of ICT essential" (MoE, 2016, p.viii) in education. Additionally, it has been mandatory to integrate ICT in school education (Ministry of Education, 2013).

Undoubtedly, the advancement in ICT has opened up new choices, opportunities and 
challenges for teachers in general to transform and modify the traditional delivery mode of knowledge based on constructivist approaches. They create an environment for learners where they feel empowered to be responsible of their learning (Cochrane, 2010). Notwithstanding, the role of teachers in this mode with technology integration is still very crucial and they need some sound skill and knowledge of technology to frame the subject content under technological pedagogical and content knowledge (TPACK). It guides teachers on how to integrate technology for teaching/learning purposes (Koehler, Mishra, \& Rosenberg, 2013).

The TPCK framework of Mishra and Koehler (2006) emphasizes, as shown in Figure 1 below, the complex interplay of the three bodies of knowledge: content (C), pedagogy $(\mathrm{P})$ and technology $(\mathrm{T})(\mathrm{p} .1025)$ :

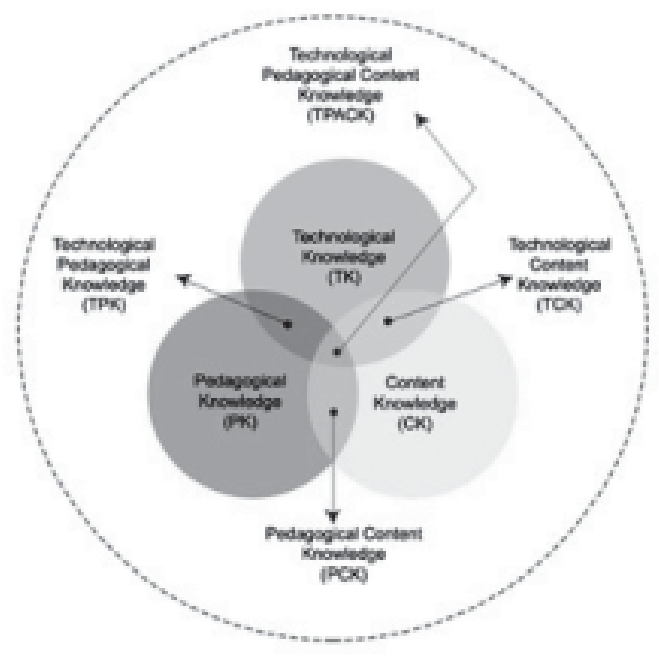

Figure 1. The TPACK Model (Mishra \& Matthew J. Koehler, 2006)

The complex inter-relationship among the three types of knowledge results in seven types of knowledge,vis-a-vis, content knowledge (CK), pedagogical knowledge (PK), pedagogical content knowledge (PCK), technological knowledge (TK), technological content knowledge (TCK), technological pedagogical knowledge (TPK) and technological pedagogical and content knowledge (TPACK). Further, Mishra and Koehler (2006) stress that technology professional development should be framed under a wide range of skills that help teachers to develop a deeper understanding of the concepts and skills of pedagogy, content together with technology. However, the ICT trainings so far have been given to teachers are primarily focused on basic technology skills which are not sufficient for them (Varisdas \& Glass, 2005). These ICT trainings programs are limited to technical skills, such as how to operate a specific software or something like that rather than making them able to integrate technology in teaching (McKenzie, 2001). Thus, technology use in education is focused on either access, infrastructures and administrative tools or performing lowlevel tasks like word processing and communication (Gray, Lewis \& Thomas, 2010).

\section{ICT integration in Nepalese education}

Innovative technology integration in the world education system has greatly influenced the education system in Nepal from school to university. Thus, ICT integration in Nepalese education system in general and in the school education in particular is highly significant. Tribhuwan University and other regional universities have already launched the courses: B. Ed and M. Ed. in ICT for pre-service teacher education (MOE. 2013). Similarly, Kathmandu University, School of Education has integrated ICT with special courses in M.Ed. and M.Phil. (KUSOED, 2015). These courses may impart future 
teachers the skills and knowledge of ICT integration for their professional development.

Master Plan (MOE, 2013) in the supported initiatives of UNESCO, Bangkok and UNESCO, Kathmandu, mentions that the revised IT Policy (2067/2010), National Plan for Action (NPA 2001-2015), School Sector Reform Plan (SSRP 2009-2015), and Three Year Plan (TYP 2011-2013) of the Government of Nepal worked initially for the development and integration of ICT in education. Similarly, School Sector Development Plan (SSDP, 2016 to 2023) through the Ministry of Education (MOE, $2013 / 2016$ ) has taken some initiatives in order to upgrade schools and teachers for imparting quality education with the help of technology integration in teaching/ learning. Particularly, the improved teaching of English as a subject and the professional development of English teachers to integrate modern technologies and the use of multimedia resources $(\mathrm{MoE}$, 2016) are the special initiatives. They may support the teaching of English as a foreign language (EFL) in schools through the integration of ICT tools/resources.

Based on the background of the above scenario, this study was mainly aimed at exploring EFL teachers' lived experiences and practices of technology integration in teaching English. It also explored some possible impediments of utilizing technology into their classroom instruction.

The following central questions were framed the study under qualitative research design;

- How is the EFL teachers' experiences and practices of technology integration into their classroom instruction?

- What are the possible impediments of utilizing technology into teaching English as a foreign language (EFL)?

\section{Objectives of the Study}

The main objectives of this study were;

- to explore EFL teachers' experiences and practices of technology utilization into their classroom instruction and

- to find out some possible impediments of technology integration into their teaching practices

\section{Literature Review}

Some recent empirical studies carried out globally on utilization of technology in teaching/learning ESL/EFL were reviewed to get some insights to guide this study. Moreover, the review consists of pedagogical potentials of modern technologies, ESL/EFL teachers' and students' perceptions/experiences and barriers of integrating innovative technologies into their practices.

\section{Pedagogical Potentials of Modern Technology}

Some studies (Bell, 2010; Pereira-Leon, 2010; Shapley, Sheehan, Maloney \& Caranikas-Walker, 2011) found that technologically enthusiastic teachers used technology in project-based learning (PBL) and believed that it provided the students with rich, authentic experiences through dialogical interactions. Additionally, the studies revealed that teachers used technology for professional development, personal purposes, and as a pedagogical tool to foster learning for acquiring some skills of the $21^{\text {st }}$ century; communication, collaboration and negotiation. In their study, Yunus, Lubis, and Lin (2009) found that mostly students manipulated the ICT gadgets for searching words' meaning and pronunciation, and getting information. Further, they revealed that ICT could "enhance their language learning in 
vocabulary, grammar, writing, speaking and allows them to take greater control of their own learning" (p. 1458). On the contrary, some studies (Bude, 2009; Capo \& Orellana, 2012; Pereira- Leon, 2010) revealed that more experienced teachers were the most reluctant to infuse technology as an instructional tool because they viewed themselves as the authority or expert in the subject and fixed to teachercentric approach. Further, they felt threatened in two ways; due to presence of additional source of knowledge available to students and due to techno-savvy students.

Lei (2010) found that social networking sites had positive impact on students to develop the skills of socialization, cultural awareness, collaboration, negotiation of meaning. Additionally, entertainmentexploration use of technology improved their learning habits. Some studies (Lomicka \& Lord, 2012; Koenig, 2011) carried out on the use of Twitter in teaching language, found to have positive impacts on students learning French and it promoted collaboration among students in an English class. Similarly, discussion forums, Facebook, Skype, Whatsapp, My Space, email, blogs, wikis, YouTube, powerpoint presentation etc. were found to have pedagogical values in teaching/learning ESL/EFL. They promoted language skills and aspects (Akdag \& Ozkan, 2017; Awada \& Ghaith, 2014; Butler, 2010; Okan \& Taraf, 2013). Moreover, they were found to be highly motivational for learners to get engaged in maximizing; analytical and critical thinking, learner autonomy, social networking and interaction skills. Shy students were found to be more expressive on their own. However, Butler (2010) reported to have some shortcomings in terms of cyberbullying, sharing inappropriate content and violent content.

\section{Teachers' and Students' Perceptions of Technology Utilization}

Several previous studies show that teachers know the potentials of teaching/learning with technology but they are cautious about utilizing it into their practices. They still have some gaps in their technology knowledge and skills (Bingimlas, 2009; Newa, 2007; Thapaliya, 2014).

Afamasaga-Wright and Farita (2008) carried out a study on teachers' perceptions of ICTs in a secondary school in Soma, found that ICTs were mainly used to support teacher-centered pedagogies. Though the teachers were interested to use technologies in their classes, they showed the lack of ICT skills and insufficient pedagogical knowledge that hindered them. Sime and Priestley (2005) found that when teachers were enthusiastic and dedicated to plan and give students wordmeaning tasks on the computer. They were more involved in their learning with technology even with limited resources in a problematic context and, "students thought that the individual teachers' attitude was the vital factor in determining ICT use" (p. 137).

Similarly Newa (2007) explored teacher effectiveness in relation to work satisfaction, media utilization and attitude towards the use of ICT among public and private secondary school teachers of the Kathmandu valley. He took 300 teachers of different academic disciplines; language, science, mathematics and social sciences. The quantitative analysis of data revealed that both; public and private school teachers exhibited comparable effectiveness whereas language teachers were found least satisfied with respect to job concentrate and economic factors compared to the other teachers. Moreover, both types of teachers believed that ICT could bring changes in teachers' role to 
increase quality of teaching and learning. However, the study could not do intensive research on EFL teachers' usage of technology integration in teaching.

Thapaliya (2014) conducted a descriptive qualitative study to explore secondary level English teachers' perceptions and practices of ICTs. Forty seven English teachers were randomly selected from secondary and higher secondary public schools in Kathmandu district. The data was collected through questionnaire were analyzed descriptively in simple statistics. It revealed that mostly EFL teachers used radio, television, mobile phone and computer. Very few teachers used email, LCD, OHP, Google talk, Skype, Web Quest, Web blog, and Web chat in the ELT classroom. Moreover, the study found that ICT could be highly motivational to make students more creative, analytic and constructive. However, some challenges such as inappropriate ICT infrastructure, large class and lack of training to teachers were found to hinder their classroom instruction with technology. The study was carried out on mixed participants that could not determine the ICT practices and experiences of either public or private secondary EFL teachers well. It could only generalize the findings of the study. Therefore, the present study would fill that gap by carrying an in-depth study being focused on public secondary school EFL teachers' utilization of technology into their classroom pedagogy.

\section{Barriers of Technology Integration}

Some studies on the barriers of technology integration at schools (BECTA, 2004; Ertmer, 2005) found that teachers' attitude was not just a personal dynamic, it was strongly influenced by the infrastructure and support available to teachers for integrating technologies into their practices. Similar studies (Nikolopoulou \& Gialamas, 2016; Awan, 2012) highlighted that some factors such as access to equipment, training and support of the education community influenced teachers' attitudes to integrate technology into their teaching. Afamasaga-Wright and Farita (2008) found that the teachers perceived some other challenges to effective integration of ICTs such as insufficient number of computers, time constraints, a user pay system, maintenance and running costs, students plagiarize from the web and access to inappropriate sites along with inadequate teacher professional development training in ICT integration. Similarly, Tella, Tella, Toyobo, Adika, and Adeyinka (2007) found that teachers' 'technology refusal happened due to "inadequate knowledge to evaluate the role of ICT in teaching and learning, lack of skills in the use of ICT equipment and software had resulted in a lack of confidence in utilizing ICT tools" (p.14).

Though teachers' beliefs and attitudes are core factors for successful integration of technology in teaching, ICT infrastructure, training, administrative support etc. are equally required to scaffold them. A study carried out by Mafuraga and Moremi (2017) found that "lack of ICT knowledge along with inadequate ICT infrastructure, limited ICT skill of students and teachers is caused by limited training at teacher training institutions on how to infuse technology into the English language teaching. Generally, the teachers' knowledge on ICT is not at par with their qualifications and experience in the field" (p. 149).

In short, the review of literature shows that the utilization of modern technology and the Internet in teaching/learning ESL/EFL has underpinned constructivist pedagogy for classroom practices. Moreover, the literature reviewed highlights some barriers linked to external factors such as lack of appropriate ICT infrastructure, technical support, time constraints, teacher 
work load, lack of ICT professional development trainings for teachers (Mafuraga \& Moremi,2017; Nikolopoulou \& Gialamas, 2016; Awan, 2012). Similarly, some barriers related to internal factors such as ESF/EFL teachers' self-efficiency, confidence, beliefs and attitudes were found to inhibit their technology acceptance, and are often regarded as more crucial than the external factors (Sime and Priestley, 2005).

The studies so far reviewed were found to have some research gaps in terms of place and participants along with research design. Eventually, no any such qualitative research has been carried out yet that could be solely focused on public secondary schools in Nepal. Therefore, the findings of this study would be highly significant for school stakeholders, researchers and policy makers to promote ICT utilization especially in teaching/learning EFL.

\section{Theoretical Perspective}

The theoretical standpoint of this study is based on the learning theory of constructivism that underpins Piaget's (1957) cognitive constructivism and Vygotsky's (1978) social constructivism together they interplay for knowledge construction. Social-cognitivist learning theory works in two ways, "Piaget's cognitive development theory can frame the tasks in the classroom while Vygotsky's theory of social interaction can be applied when the students are doing the tasks" (Alsulami, 2016, p. 105). These two are intertwined because they are in reciprocal relationship as society itself does not think and individuals need social contexts for their thoughts to evolve (Fosnot, 1996). Hence, these two strong versions of constructivism have changed the traditional views about teaching and learning.

Moreover, in constructivist teaching/ learning approach, technology has been given prime importance to scaffold students' learning in order to construct knowledge on their own. Asiksoy and Ozdamli (2017) opine, "Information construction does not only happen with the learner interaction in their physical environments, it is also constructed with the interactions in social and technological environments in an active way" (p.134). Thus, the proper use of educational technology can be best practiced in constructivist approach (Hong \& Lin, 2010) because the modern technology has potentials to support students and teachers for knowledge construction, reflective thinking, learner autonomy, collaboration and interaction regardless of time and place.

\section{Methodology}

The study was designed under the theoretical insights of constructivism that advocates for subjective and multiple realities of a social phenomenon. Qualitative research approach was used to explore the subjective experiences and practices of EFL teachers from their everyday classroom instruction. Since a qualitative research is used to explore the 'why' and 'how' of the phenomenon for a deeper understanding (Kemparaj \& Chavan, 2013), it deliberately employs a small purposeful sampling strategy to collect the relevant data for in-depth studies (Maxwell, 2013). Thus, eight EFL teachers were purposefully recruited on the basis of their technology integrated teaching practices from public secondary schools of three districts; Kathmandu, Lalitpur and Bhakatpur (the Kathmandu valley). Similarly, the schools were also recruited on the basis of purposive judgmental sampling in terms of availability of modern technology tools and Internet connectivity.

Semi-structured interview was chosen as a tool for the data collection. It provides 
detailed information for deep understanding of the participants' lived experience (Yilmaz, 2013) and is flexible in nature that gives space for emerging issues during the interview. The interview was guided by a set of twenty one questionnaires based on the objectives of this study.

\section{Participants and Procedures}

The eight purposefully selected EFL teachers were given pseudonyms to ensure the research ethics and confidentiality of the research participants. They were selected on the basis of a number of factors such as gender, school location and category, teaching experience with technology utilization. The equal number of male and female EFL teachers (4/4) were selected from public secondary schools of the Kathmandu valley. They were asked for their written consent to participate in the study and made them assured of confidentiality of their responses.

\section{Data Interpretation and Findings}

The digitally recorded interview data were in the English language as they were obtained from the EFL teachers. They were converted into the textual form for analysis. Further, they were coded and clustered to generate themes based on the research questions. The following themes were generated from the collected data for analysis under two main categories and subcategories;

\section{EFL teachers' experiences and practices with technology utilization}

The data collected from the participants being focused on their pedagogical practices with technology utilization and associated factors were analyzed under four sub-themes;

\section{EFL teachers' preparedness for technology integrated instruction:}

EFL teachers' preparedness for technology utilization in teaching refers to their professional training on technology integrated instruction and their experiences of it. All of the participants were found highly enthusiastic and motivated for technology supported EFL instruction. They agreed that modern ICT tools and resources helped them extensively in order to transfer the traditional instructional mode of 'Chalk \& Talk' into constructive mode of instruction. One of the participants, Hari mentioned:

For teaching English, computer can be found easier rather than other subjects because many materials can be found easily in the net especially for teaching English e.g. all listening, reading, speaking, writing, and grammar and vocabulary. So if students feel any difficulty in finding the word certainly they will search there in the net and then synonyms, antonyms and some other parts of speech can be found easily.

The EFL teachers' pedagogical practices with technology were found to be based on their basic skills of computer usage, net surfing for downloading authentic materials, audio-videos from YouTube, using email and social networking sites (SNSs) like Facebook, Messenger, Instagram, WhatsApp, and IMO for informing students about academic activities and assignments. A participant, Gopal stated:

Those trainings were quite the basic trainings just how to operate the keyboard, mouse etc. and then I've not gone through any specific trainings like window packages etc. I, myself made effort to study and use those materials ... SMART board, internet etc. 


\section{Strategies of integrating ICT tools for teaching EFL skills and aspects}

Though the participants were found to have been using computer and the Internet for their classroom practices for a long time, many of them had very basic skills of computer technology. Many of them had taken three months package course and even some had managed such skills informally. Consequently, they were unable to utilize ICT tools and resources to a greater degree for enhancing their pedagogical practices. They revealed that they used technologies for power-point presentation of their teaching contents, downloaded audio, video and other required materials like movies, stories, poems, dramas, biographies etc. related to the EFL course from YouTube and Google. Sarita mentioned:

...some of the poems are there ... collect some of the videos from Google or YouTube and demonstrate here then they can understand the gist very easily than the lecture method. There are some dramas ... these materials, video materials, audio materials from net.

All the participants were found to have recognition of the educative value and potentials of modern technology for transferring traditional mode of instruction to interactive mode for promoting students' independent knowledge construction. Therefore, they were quite positive and highly enthusiastic to put their personal effort for pedagogical usage of the available technology at their school. Lalita reflected:

For the flip activities mostly I use that documentaries and video clips and then sometimes according to that in our course book there're some stories also very much related stories ...in a video form, we can find and ...showing them that videos ... in class ' 9 ' there's the one 'Jhola' movie, I just took all my students to the ICT lab showed them that ...next day we discuss in the classroom ...yes, they're very enthusiastic.

Thus, all the participants were found to have similar pedagogical strategies for integrating instructional technology into their EFL practices. Almost all used technology for power-point presentation, searching audio, video and textual materials from Google, YouTube, mobile dictionaries etc. for facilitating their classroom practices.

\section{Effect of technology integrated instruction on students' motivation and achievement/performance}

All the participants agreed that technology played a great role to motivate students for their active and interactive participation in teaching and learning activities. Further, they revealed that educational technology could bring noticeable changes in students' EFL achievement in terms of pronunciation, vocabulary, communication and intercultural competence. They could practice EFL skills independently with the help of ICT tools and the Internet. They found authentic materials and exposure of English on the Internet. As Mohan stated:

...teaching with ICT is more effective and more interesting and the students can keep all these things in their memory for long time because it's visualized.

Similarly, Sohan expressed his view in favor of ICT integration that promoted students' performance and brought remarkable change in their achievement. He expressed:

...they prefer the visual classes mostly. They were able to store the information in their mind after having the visual of the different items in the class, their achievement level has increased. 
Some of the participants reflected that their students seemed smarter than them in operating technology. They assisted them in managing and integrating ICT tools for instruction. Gopal stated:

They mostly prefer these modern technology and they're far superior than us ... they're smart and really we're a bit older in comparing to them.

\section{Support from school administration, DEO, NCED, DOE, and NGOs/INGOs}

Along with EFL teachers' self-efficiency and confidence for bringing and accepting the global change in pedagogy, they certainly need some support from school administration (admin), District Education Office (DEO), National Center for Education Development (NCED), NonGovernment Organizations (NGOs)/ International Non-Government Organizations (INGOs) and community too. As technology integrated instruction is a recent phenomenon in Nepalese school education, the in-service EFL teachers particularly require continuing professional ICT skills and knowledge, adequate ICT infrastructure at school and research based orientation from education authorities and stakeholders regularly.

All the participants were in-service EFL teachers. They all agreed that their skills and knowledge in terms of technology supported instruction were not sufficient as they had only some basic computer skills. Moreover, they were found to utilize the available ICT infrastructure at school in order to facilitate their classroom practices. They acknowledged that their school admin and DEO were supportive for ICT integrated instruction. Gopal reflected:

DEO is supportive because sometimes they're providing us computers and then they encourage us to make our school SMART school because their consent mainly could help us ...Samsung company wanted to give us and their consent was necessary that they (DEO) gave ...

In short, EFL teachers' self-efficacy and confidence in ICT skills and knowledge along with support from school admin, DEO, NCED and NGOs/INGOs were found to be the determining factors for sustainable utilization of technology into their classroom practices.

\section{Possible impediments of technology integrated EFL instruction}

The participants were asked for their professional preparedness in order to ICT integrated EFL teaching. They revealed the fact that their technology skills and knowledge were insufficient for classroom practices. Consequently, they were unable to utilize ICT tools extensively in the lack of professional ICT skills and knowledge of classroom instruction that Mishra and Koehler (2006) termed as technological pedagogical and content knowledge (TPACK). Mohan reflected:

Teachers are not well trained but have good practice ... the government organizes one day or two days ICT training programs...

All the participants agreed that the government had neither given adequate support for ICT infrastructure at school nor given adequate professional ICT training based on the TPACK framework designed by Mishra and Koehler (2006) to EFL teachers for their professional development. They insisted that ICT professional training should be compulsorily given to all teachers in general and should be made compulsory to integrate in their pedagogy. Lalita excitedly expressed: 
... first of all this ICT training should be given to all the teachers. It should be made compulsory. ... some of the teachers are learning and some are neglecting this.

\section{Related to students, teachers' workload and time constraints, and ICT infrastructure at school}

Teaching and learning is a process that is related with many factors, not only teachers and school admin but also students, time constraint and workload of teachers, and ICT infrastructure at school. All the participants referred to these factors as integral parts of pedagogy. They expressed their view that at public secondary schools, the majority of students came from lower middle class family that could not afford them ICT tools such as computer, mobile, tablet, and internet connectivity at home. It seemed there existed digital divide among students. Those who had ICT tools at home could practice and do school assignments easily whereas those who did not have either go to cyber or would not practice even if they wanted. Babita reflected:

Most of them don't have because our source students are from lower middle class so most of them don't have but some of them have ... they go to cyber to do the assignments ...

The participants viewed digital divide as an impediment in the sense that they wanted their students should practice at home for better performance. Some of the participants indicated one more problem related to students that their low English background could create troubles for them to understand English while they were provided with authentic audio-video materials from the Internet. Sohan stated:

The first challenge, almost all students are not able to catch up the exact pronunciation of the native speakers whenever I show them because I think they don't have such kind of environment at home. They use English only in my period..

Time constraint and workload at school were also found as posing challenges for EFL teachers to conduct classes with ICT resources. They had time limitation of 45 minutes each period. They had to complete their teaching/learning activities such as managing students sitting in the ICT lab with limited number of computer resources, facilitating about the audio-video activities and having discussion afterwards made them feel to have some more time for ICT integrated instruction. Moreover, the large number of students in each class was also viewed as a challenge for EFL teachers to allow students sufficient practice either in group or individually. Additionally, EFL teachers were found to be fully engaged for $6 / 7$ periods a day that showed the lack of leisure time in regard of planning the lessons for ICT integration. Therefore, they were found to be compelled to have limited frequency of technology integrated instruction i.e. once a week and sometimes once a month even. Lalita mentioned: Not always, I don't use... ICT tools to teach
my subject matter, not everyday but
sometimes, let's once a week, once a
fortnight...

Gopal reflected:

... once a week at least I try to use.

Another impediment appeared in terms ICT infrastructure at school. Most of the schools were found to have average availability of ICT tools limited to one room i.e. ICT lab which had 30/40 computers, SMART board, multimedia, laptop, projector, white board, television, CD players, sound systems and the Internet connectivity. Some schools had only $6 / 7$ computers and WiFi connectivity as 
minimum ICT infrastructure. The participants found it quite challenging for them to conduct technology supported instruction with minimum technology resources at school even if they were willing to have. Hari reflected:

... so not sufficient amount of tools so we've been facing some of the challenges ...

lack of technical support and skill.

Along with ICT infrastructure, all the participants pointed out that as they had limited ICT skills and knowledge in order to handle the ICT tools, they faced some technical problems and the school did not have any technician for ICT lab.

\subsection{Related to school admin, DEO, NCED, and NGOs/INGOs}

The participants agreed that the role of school administration was crucial to avail the adequate resources and to manage opportunities for continuing professional development (CPD) on how technical knowledge should be incorporated into pedagogical content knowledge in order to update teachers' capacity in general from different resources such as DEO, NCED, DOE, and NGOs/INGOs and community. They revealed that their school admin tried its best to promote technology supported instruction at schools, however, the conventional mode of education system from top to down posed various challenges such as traditional curriculum, large/ crowded classroom, training to teacher, limited budget, inadequate ICT infrastructure, teacher workload, product oriented instruction etc. Though, MoE brought ICT policy in education and attempted to train in-service teachers through different recourse centers and departments (DEO, NCED, DOE, CDC), very few got such opportunities and even those training were not effective, as Sarita declared:

From DEO, I got a training, a three month training, not only in case of me, per year they're trying to give to the teachers... turn-wise. Some of the teachers are getting from the part of DEO or MOE and NGOs/ INGOs time to time ... but we're not getting any effective ideas.

A number of teachers did not get any opportunity for professional ICT training from any organizations as Kabita expressed:

Right now I've not participated in any training from those organizations, not at all till now, maybe, they will be providing in future.

Technology supported pedagogy basically requires constructivist approaches for teaching and learning that are process oriented. But the conventional system of education is product oriented that compels school administration to be focused on final examination. Consequently, teachers are compelled to complete their courses in time so that they tend to avoid technology integrated instruction. All of the participants viewed ICT based instruction time-consuming and additionally some of the school administrations did not pay attention for it even if the teachers wanted. Lalita stated:

... time is not there, we're not allowed then why to go ... we don't take students frequently in the ICT lab, even though we want...

Despite these challenges, all the participants were found to be highly motivated for technology integrated classroom practices. Even though they did not have adequate and sufficient professional ICT skills and knowledge for planning their EFL lessons on the TPACK 
framework, they were eager to conduct classes utilizing ICT tools and innovative technology along with some support of school administration, DEO, NCED, and NGOs/INGOs.

\section{Discussion and Implications}

As this study has been grounded under the theoretical prospective of constructivism, the findings were discussed in the light of it. Additionally, the discussion is comprised around two key issues:

i. Technology utilization in teaching English at secondary level

ii. Possible impediments of technology utilization in teaching/leaning

\section{Technology utilization in teaching English at secondary level}

The theory of constructivism advocates for socio-cognitive aspect of knowledge construction in which technology could play a vital role to support teachers and students (Hong \& Lin, 2010). Teaching and learning approaches of constructivism are constructive and collaborative that promote teachers to facilitate their classroom instruction by utilizing technology. Moreover, the findings from the data analysis suggested that EFL teachers at public secondary schools were highly motivated and positive to utilize different ICT tools to facilitate their classroom pedagogy. Similarly, EFL teachers' preparedness for technology integration revealed that they were highly motivated and enthusiastic to bring pedagogical changes into their profession. However, their professional ICT skills and knowledge were found to be limited to basic computer skills that required to be updated with sufficient and adequate professional ICT trainings.
Furthermore, EFL teachers were found to utilize ICT tools/resources for power-point presentation, downloading audio, video and text or authentic materials from Google and YouTube, used email and some social networking sites (SNSs) such as Facebook, Messenger, Whatsapp, Instagram, and IMO for more interaction with students. Their pedagogical utilization of technology, though in a nutshell, promoted studentcentered instruction.

All the participants equally agreed that technology supported instruction was greatly motivating for students and increased level of their achievement. They were more active, interactive and participatory in comparison to traditional 'chalk and talk' mode of instruction. They stated that their students were highly cooperative, enthusiastic and wanted ICT supported instruction frequently. This finding co-relates with the findings of the previous studies (Afamasaga-Wright \& Farita, 2008; Lei, 2010) that highlight technology integrated instruction promotes constructivist approaches of studentcentered classroom practices. Further, the study also found that the EFL teachers highly required support from school administration, DEO, NCED, DOE, CDC and NGOs/INGOs for their professional ICT capacity building training orientations, adequate ICT infrastructure at school, curriculum and technology co-relation for effective classroom practices, teachers' workload and time constraint overview, product-orient approach etc. needed more consideration.

\section{Possible impediments of technology utilization in teaching/ leaning}

The findings on the possible impediments of utilizing technology in EFL teaching/ learning brought many issues in light such as insufficient professional ICT skills and 
knowledge of EFL teachers, teachers' workload and time constraint, students' digital divide, insufficient availability of ICT infrastructure at school, and insufficient support from school admin, DEO, NCED, DOE, CDC, MOE and NGOs/ INGOs. These were highly influential external factors that EFL teachers' recognized as impediments of technology integrated instruction. These findings go in a line with some previous studies (Awan, 2012; Mafuraga \& Moremi, 2017; Nikolopoulou \& Gialamas, 2016; Thapaliya, 2014).

Moreover, the studies (Bude, 2009; Capo \& Orellana, 2012; Pereira- Leon, 2010; Sime \& Priestley, 2005) revealed that the main barriers of ICT integrated instruction were basically related to internal factors such as teachers' negative attitudes and perception, lack of confidence, reluctant to accept change, techno-phobia etc. on the contrary, Nepalese EFL teachers of public secondary schools were found to be highly positive, motivated and enthusiastic. Even if they lacked sufficient ICT skills and support, they were still greatly ready to go for technology supported instruction. It is quite praiseworthy.

\section{Conclusion}

This study was conducted to address the research gap that existed at public secondary schools particularly related to the EFL teachers' utilization of technology into their classroom practices and possible impediments of technology utilization in teaching and learning EFL. This study is context specific that is limited to EFL teachers of public secondary schools of the Kathmandu valley and its findings cannot be generalized to all EFL contexts in Nepal. Further, the data analysis of semistructured interview of eight EFL teachers suggest some findings that although EFL teachers are not professionally well-trained for technology integrated instruction, they are highly positive and motivated. Similarly students are greatly co-operative and enthusiastic for developing communicative and intercultural competence along with linguistic competence through studentcentered classroom practices with the help of ICT tools and resources.

The findings also highlights the need of sufficient support from school education authorities and different organizations to empower EFL teachers and schools with required teachers' professionalism and ICT infrastructure. Additionally, this study recommends for more in-depth studies on EFL teachers' and students' perception of technology supported instruction, EFL teachers' preparedness for TPACK, school/ EFL syllabus/curriculum and instructional technology inter-connectedness are the specific areas for future research.

\section{References}

Afamasaga-Wright and Farita Tepora. (2008). Teacher Perceptions of Information and Communication Technologies in a Secondary School in Samoa. Retrieved from www.researcharchive.vuw.ac.nz/ handle/10063/688.

Akdag, E. \& Ozkan, Y. (2017). Enhancing writing skills of EFL learners through blogging. The Reading Matrix: An International Online Journal, 17(2), 7995.

Alsulami, S. (2016).Toward a Constructivist Approach in Saudi Education.English Language Teaching, 9(12), 104-108.

Asiksoy, G. \& Ozdamli, F. (2017). An overview to research on education technology based on constructivist learning approach.Cypriot Journal of Educational Science.12(3), 133-147. 
Awada, G. \& Ghaith, G. (2014). Effect of using the blog educational tool on writing achievement and motivation for legal writing.International Journal of Education and Research, 2(12), 371388.

Awan, R.N. (2012). A study of teachers' opinions and experiences on the use of computers and laptops in classrooms in the United Arab Emirates.2012 International Conference on Management and Education Innovation.IPEDR, 37, 257-268.

BECTA, (2004). What the research says about ICT and continuing professional development (CPD) for teachers. Coventry, British Educational Communications and Technology (BECTA).

Bell, S. (2010). Project-based learning for the 21st century: Skills for the future. The Clearing house, 83(2), 39-43. https:// www.tandfonline.com/doi/abs / 10.1080/00098650903505415

Bingimlas, K. (2009). Barriers to the successful integration of ICT in teaching and learning environments: A review of the literature. Eurasia Journal of Mathematics, Science $\mathcal{E}$ Technology Education, 5(3), 235-245.

Bude, S. (2009). Effective technology integration: Old topic, new thoughts. International Journal of Education and Development using Information and Communication Technology, 5(2), 161172.

Butler, K. (2010). Tweeting your own horn. District Administration, 46(2), 41-44.

Capo, B. H., \& Orellana, A. (2012). Web 2.0 technologies for classroom instruction: High school teachers' perceptions and adoption factors.
Quarterly Review of Distance Education, 12(4), 235-246.

Cochrane, T. (2010). An mlearning journey: MobileWeb 2.0 critical success factors. Paper presented at the MLearn 2010: The 9th International Conference on Mobile Learning, Valletta, Malta, 26 30 October.

Ertmer, P. A. (2005). Teacher pedagogical beliefs: The final frontier in our quest for technology integration? Educational technology research and development, 53(4), 25- 39.

Fosnot, C. T. (1996). Constructivism: A psychological theory of learning. In Constructivism: theory, perspectives and practice, (Ed.) C. T. Fosnot, 8-33. New York: Teachers' College Press.

Gray, L., Thomas, N., \& Lewis, L. (2010). Teachers' Use of Educational Technology in U.S. Public Schools: 2009 (NCES 2010-040). National Center for Education Statistics, Institute of Education Sciences, U.S. Department of Education. Washington, DC.

Hong, H. Y, \& Lin, S. P (2010).Teaeheredueation students' epistemologieal beliefs ehange through eollaborative knowledge building. The Asia-Pacific Education Researcher, 79(1), 99-110.

Horovitz, B. (2012). After Gen X, Millennials, what should next generation be? USA Today, 4 May. Retrieved January, 2018, from http:/ /usatoday30.usatoday.com/money/ advertising/story / 2012-0503/ naming-the-next- generation/ 54737518/1.

Kathmandu University School of Education. (2015). Master's degree program: Program brochure, 2015. Lalitpur, Nepal: Author.

$166 \quad$ Journal of NELTA, Vol 23 No. 1-2, $\quad$ December 2018 
Kemparaj, U. \& Chavan, S. (2013). Qualitative research: A brief description. Indian Journal of Medical Sciences, 67(3-4), 89-98.doi:10.4103/ 0019-5359.121127.

Koehler, M. J., Mishra, P., Akcaoglu, M. and Rosenberg, J. (2013). The technological pedagogical content knowledge framework for teachers and teacher educators. In ICT Integrated Teacher Education: A Resource Book, (ed.), R. Thyagarajan, 2-7. New Delhi: Commonwealth Educational Media CeT.

Koenig, D. (2011). Social media in the schoolhouse.Teaching Tolerance, 39, 4245. https://www.tolerance.org/ magazine/spring-2011

Lei, J. (2010). Quantity versus quality: A new approach to examine the relationship between technology use and student outcomes. British Journal of Educational Technology, 41(3), 455-472.

Lomicka, L., \& Lord, G. (2012). A tale of tweets: Analyzing microblogging among language learners. System. An International Journal of Educational Technology and Applied Language, 40(1), 48-63.

McKenzie, J. (2001). How teachers learn technology best. The Educational Technology Journal.10(6).

Mafuraga, M. \& Moremi, M. (2017). Integrating Information and Communication Technology in English Language teaching: A case study of selected Junior Secondary Schools in Botswana. International Journal of Education and Development using Information and Communication Technology (IJEDICT), 13(1), 142-152.
Maxwell, J. (2013). Qualitative research design: An interactive approach (3rd Ed.). Thousand Oaks, CA: Sage.

Ministry of Education. (2013). Information and communication technology (ICT) in education: Master plan 2013-2017. Kathmandu: Ministry of Education, Government of Nepal.

Ministery of Education. (2016). School Sector Development Plan, Nepal, 2016-2023. Kathmandu: Ministry of Education, Government of Nepal.

Mishra, P., and M. Koehler. (2006). Technological Pedagogical Content Knowledge: A New Framework for Teacher Knowledge. Teachers College Record. 108(6), 1017-1054.

Newa, D. R. (2007).Teacher effectiveness in relation to work satisfaction, media utilization and attitude towards the use of information and communication technology (ICT) among secondary School teachers of Nepal. Unpublished PhD dissertation: Panjab University, Chandighrdh.

Nikolopoulou, K., \& Gialamas, V. (2016). Barriers to ICT use in high schools: Greek teachers' perceptions. Journal of Computers in Education, 3(1), 59-75.

Okan, Z. \& Taraf, U.H. (2013).The use of blogs in second language teacher education.Procedia - Social and Behavioral Sciences, 83(2013), 282 289. www.sciencedirect.com

Pereira-Leon, M. J. (2010).Constraints, resources, and interpretive schema: Explorations of Teachers' decisions to utilize, under-utilize or ignore technology. Doctoral dissertation. Indiana University: Bloomington. 
Piaget, J. (1957). Construction of reality in the child. London: Routledge \& Kegan Paul.

Shapley, K., Sheehan, D., Maloney, C., \& Caranikas-Walker, F. (2011). Effects of

Technology immersion on middle school students' learning opportunities and achievement. The Journal of Educational Research, 104(5), 299-315.

Sime, D., \& Priestley, M. (2005). Student teachers' ûrst reûections on information and communications technology and classroom learning: Implications for initial teacher education. Journal of Computer Assisted Learning, 21(2), 130-142.

Tella, A., Tella, A., Toyobo, O. M., Adika, L. O., \& Adeyinka, A. A. (2007). An assessment of secondary school teachers' uses of ICTs: Implications for further development of ICT's use in Nigerian secondary schools. The Turkish Online Journal of Educational Technology, 6(3), 1-13.

Thapaliya, M.P. (2014). English Teachers' perceptions and practices of Information and Communication Technologies (ICTs) in Kathmandu District, Nepal, International Journal of Academic Research in Education and Review, 2(10), 251-258 DOI: 10.14662/IJARER2014.056

Vrasidas, C. and Glass, G. (2005). Achieving technology integration in classroom teaching. In: Vrasidas, C. and Glass, G. Eds. (2005). Preparing teachers to teach with technology. Connecticut, Information Age Publishing

Vygotsky, L. S. (1978). Mind in society: The development of higher psychological processes. Cambridge, MA: Harvard University Press.
Yilmaz, K. (2013). Comparison of quantitative and qualitative research traditions: Epistemological, theoretical, and methodological differences. European Journal of Education, 48(2), 311-325.doi:10.1111/ ejed.12014.

Yunus, M. M., Lubis, M. A., \& Lin, C. P. (2009). Language Learning via ICT: Uses, Challenges and Issues. Wseas transactions on information Science and applications, 6(9), 1453 - 1467.

\section{Contributor}

Renu Singh is a lecturer in English Education at Thakur Ram Multiple Campus, Birgunj, Tribhuvan University. She has been teaching at the campus for the last 20 years. Currently, she is a Ph.D. scholar under Norhed Quantic Project, Faculty of Education, Tribhuvan University, Kathmandu. She has published journal articles and co-authored a textbook on Academic Writing. Her research area is ICT integration in teaching English at School. 